\title{
Promoter methylation of RASSF I A and DAPK and mutations of K-ras, p53, and EGFR in lung tumors from smokers and never-smokers
}

\author{
Yang Liu1 ${ }^{1}$, Weimin Gao $^{2}$, Jill M Siegfried ${ }^{3,6}$, Joel L Weissfeld ${ }^{4,6}$, \\ James D Luketich ${ }^{5,6}$ and Phouthone Keohavong*1,6
}

Address: ${ }^{1}$ Department of Environmental and Occupational Health, University of Pittsburgh, Bridgeside Point, Suite 350, 100 Technology Drive, Pittsburgh, PA 15219, USA, ${ }^{2}$ Department of Environmental Toxicology and The Institute of Environmental and Human Health, Texas Tech University, Lubbock, TX 79409, USA, ${ }^{3}$ Department of Pharmacology, University of Pittsburgh, Pittsburgh, PA 15261, USA, ${ }^{4}$ Department of Epidemiology, University of Pittsburgh, Pittsburgh, PA 15213, USA, ${ }^{5}$ Department of Surgery, University of Pittsburgh, Pittsburgh, PA 15213 , USA and 'University of Pittsburgh Cancer Institute, Pittsburgh, PA 15213, USA

Email: Yang Liu - yal26@pitt.edu; Weimin Gao - weimin.gao@TIEHH.TTU.edu; Jill M Siegfried - siegfrie@server.pharm.pitt.edu; Joel L Weissfeld - jwepid@pitt.edu; James D Luketich - luketichjd@upmc.edu; Phouthone Keohavong*-pho1@pitt.edu

* Corresponding author

Published: 3 May 2007

BMC Cancer 2007, 7:74 doi:10.1/86/147|-2407-7-74
Received: 4 March 2007

Accepted: 3 May 2007

This article is available from: http://www.biomedcentral.com/I47/-2407/7/74

(c) 2007 Liu et al; licensee BioMed Central Ltd.

This is an Open Access article distributed under the terms of the Creative Commons Attribution License (http://creativecommons.org/licenses/by/2.0), which permits unrestricted use, distribution, and reproduction in any medium, provided the original work is properly cited.

\begin{abstract}
Background: Epidemiological studies indicate that some characteristics of lung cancer among never-smokers significantly differ from those of smokers. Aberrant promoter methylation and mutations in some oncogenes and tumor suppressor genes are frequent in lung tumors from smokers but rare in those from never-smokers. In this study, we analyzed promoter methylation in the ras-association domain isoform A (RASSFIA) and the death-associated protein kinase (DAPK) genes in lung tumors from patients with primarily non-small cell lung cancer (NSCLC) from the Western Pennsylvania region. We compare the results with the smoking status of the patients and the mutation status of the K-ras, p53, and EGFR genes determined previously on these same lung tumors.

Methods: Promoter methylation of the RASSFIA and DAPK genes was analyzed by using a modified two-stage methylation-specific PCR. Data on mutations of K-ras, p53, and EGFR were obtained from our previous studies.

Results: The RASSFIA gene promoter methylation was found in tumors from $46.7 \%(57 / 122)$ of the patients and was not significantly different between smokers and never-smokers, but was associated significantly in multiple variable analysis with tumor histology $(p=0.031)$ and marginally with tumor stage $(p=0.063)$. The DAPK gene promoter methylation frequency in these tumors was 32.8\% (40/I22) and did not differ according to the patients' smoking status, tumor histology, or tumor stage. Multivariate analysis adjusted for age, gender, smoking status, tumor histology and stage showed that the frequency of promoter methylation of the RASSFIA or DAPK genes did not correlate with the frequency of mutations of the K-ras, p53, and EGFR gene.

Conclusion: Our results showed that RASSFIA and DAPK genes' promoter methylation occurred frequently in lung tumors, although the prevalence of this alteration in these genes was not associated with the smoking status of the patients or the occurrence of mutations in the K-ras, p53 and EGFR genes, suggesting each of these events may represent independent event in non-small lung tumorigenesis.
\end{abstract}




\section{Background}

Lung cancer, the leading cause of cancer-related death in the Unites States and worldwide, is strongly associated with tobacco smoke exposure [1]. In spite of extensive studies, the etiology of lung cancer remains poorly understood. Particularly, studies of lung cancer among neversmokers are few and little is known about the etiology of lung cancer in never-smoking patients. Some studies showed that the frequencies and/or patterns of genetic and epigenetic alterations in some genes in lung tumors from smokers differ from those in never-smokers. For instance, mutations in the K-ras oncogene, p53 tumor suppressor gene, and epidermal growth factor receptor (EGFR) gene have been found frequently in lung tumors and implicated in lung tumorigenesis. However, while Kras mutations were detected primarily in lung tumors from smokers [2-4], the EGFR mutations were found mostly in lung tumors from never-smokers [5-7]. Furthermore, although the $p 53$ mutations were detected in lung tumors from both smokers and never-smokers, the mutation types and spectra were different between the two groups of lung cancer patients $[3,8]$.

In addition to mutations in oncogenes and tumor suppressor genes, results from previous studies demonstrated that promoter methylation of some genes occurred more frequently in lung tumors from smokers, compared with never-smokers [9-13]. Other genes whose transcription has been found frequently inactivated in lung tumors include the ras-association domain isoform A (RASSF1A) and the death-associated protein kinase (DAPK) genes, but the effects of tobacco smoking on the prevalence of promoter methylation of these genes in lung tumors remain unclear. The RASSF1 gene is located at 3p21.3 and functions as a tumor suppressor gene involved in cell apoptosis, genomic and microtubule stability, and cell cycle regulation [14]. This gene codes for two major transcripts, RASSF1A and RASSF1C, by alternative splicing $[15,16]$. Promoter methylation of the RASSF1A gene has been found in many human tumors, including those of the lung where it was detected in $30 \%$ to $50 \%$ of non-small cell lung cancer (NSCLC) $[16,17]$. The DAPK gene is located on chromosome 9p34.1. It encodes for a Ca+/calmodulin-regulated serine/threonine kinase involved in apoptosis induced by interferon- $\gamma$, tumor necrosis factor $\alpha$, activated Fas, transforming growth factor $\beta$, ceramide and detachment of cells from the extracellular matrix [18]. $D A P K$ suppresses tumor growth by increasing the occurrence of apoptosis [19]. Expression of DAPK is frequently lost in many human cancers, often as a result of silencing by DNA methylation. Promoter methylation of the DAPK gene has been found in $20 \%$ to $40 \%$ of NSCLC [20,21].

It has been suggested that epigenetic changes might addict cells to certain oncogenic pathways, predisposing cells to the accumulations of genetic mutations, which drives tumor progression [22]. On the other hand, overexpression of the K-ras gene can affect the activity of methytransferase $[23,24]$ and potentially the methylation activity and regulation of gene transcription. Several studies have indicated the presence of an association between RASSF1 and Ras proteins. For instance, Ras binds RASSF1C in a GTPdependent manner to mediate apoptosis [25]. Because RASSF1A has the identical Ras associate domain as RASSF1C [15,16], RASSF1A may bind Ras in the same manner as RASSF1C. Furthermore, Ras may also promote apoptosis through its association with a Nore-RASSF1-Mst 1 complex $[26,27]$ since RASSF1A was found to be the closest Ras effector homologue to Nore1 in mammalian cells [15]. RASSF1A forms heterodimers with Nore1 through its non-homologous NH2-terminal segments and interacts with Ras [28]. Therefore, RASSF1A may serve as a Ras effector to mediate apoptosis.

DAPK and p53 may interact to mediate apoptosis. Raveh et al demonstrated that DAPK executes its anti-oncogenic action through activation of p53 in a mechanism that requires p19ARF [29] and failure to perform apoptosis may result in tumorigenesis. Other studies showed that DAPK may also exert its p53-mediated suppressive effects on oncogenic transformation by imposing growth arrest, apoptosis or both $[30,31]$.

Although EGFR mutations have been found frequently in lung tumors, the relationship between these mutations and promoter methylation in these tumors has not been well studied. EGFR is a $170 \mathrm{kDa}$ trans-membrane glycoprotein. When EGFR binds to specific ligands, multiple signaling pathways are activated, including the RAS/RAF/ ERK/MAPK pathway, resulting in cell proliferation, and the p13/AKT pathway [32]. Recently, it has been demonstrated that mutations in the tyrosine kinase domain region of the EGFR gene in NSCLC predict the response to tyrosine kinase inhibitors $[33,34]$ and enable the identification of the subpopulation of lung cancers that are likely to respond to drugs targeted to EGFRs. The EGFR mutations were found consistently more common in neversmokers [5-7], indicating different pathways for lung tumorigenesis between smokers and never-smokers. Although both genetic and epigenetic alterations in oncogenes and tumor suppressor genes have been identified frequently in lung tumors, the interaction among these gene alterations and their significance in lung cancer remains poorly understood. In this study, we analyzed methylation in the promoter region of the RASSF1A and DAPK genes in 122 lung cancer patients. We compared the results with those reported by previous studies and with the status of mutations in the K-ras, p53 and EGFR genes in the same lung tumors obtained from patients from the Western Pennsylvania region. 


\section{Methods}

Lung tumor tissues analyzed in this study were obtained from 122 lung cancer patients, including 81 smokers and 41 never-smokers, all of whom were Caucasian and lived in the Western Pennsylvania region. All 122 tumors were among specimens collected between 1988 and 2001 and stored at the University of Pittsburgh Medical Center under an Institutional Review Board-approved protocol. The demographic and clinical profiles of these patients are shown in table 1 . Of the 122 patients, 120 had NSCLC while 2 had SCLC, including one patient with carcinoid and one patient with neuroendocrine carcinoma. Most of the never-smokers were females $(31 / 41$, or $75.6 \%)$ while male patients accounted for $24.4 \%$ (10/41). The male and female patients among the smokers were 51.9\% (42/81) and $48.1 \%$ (39/81), respectively.

Each lung tumor was histologically examined by a pathologist to identify the type and other clinical characteristics of the tumor. Any contamination of tumor cells by nontumor cells was described by the pathologist. Most of the cells in these lung tumor samples were tumor cells. DNA was extracted from fresh-frozen tissues, using the Proteinase $\mathrm{K}$ treatment and phenol/chloroform method, and was dissolved in distilled water and stored at $-20^{\circ} \mathrm{C}$ until use.

\section{Methylation-specific PCR (MSP)}

Each genomic DNA sample was treated with sodium bisulfite (Sigma, Saint Louis, MO) and purified by using a Wizard DNA Clean-Up System (Promega Corporation, Madison, WI), as described previously [12]. Universal methylated human DNA (Chemicon International, Temecula, CA) was treated the same way and was used as a positive control DNA, and water was used as blank controls.

Two versions of MSP have been previously reported, including an original 1-stage MSP [35], and a modified 2stage MSP that used 2 rounds of PCR and had a higher level of sensitivity to detect promoter methylation, compared with the original 1-stage MSP [36]. We first compared the sensitivity and validity of both MSP methods to analyze promoter methylation of these genes in DNA from some lung tumors. The results showed that promoter methylation was detected in the same tumors and at a similar frequency by using either the original or modified MSP for these genes, suggesting that the original 1stage MSP was sufficiently sensitive to detect promoter methylation in lung tumors. However, in our experiments, the 2-stage MSP method showed MSP-products as one clear single band by gel electrophoresis analysis, while the 1-stage MSP method provided products that usually appeared with other minor bands (data not shown). Therefore, in this study, we applied a sensitive modified 2-stage MSP. The nucleotide sequences of the primers used for MSP analysis for both the RASSF1A and $D A P K$ were the same as described by Belinsky et al [37]. During the stage-I PCR, the PCR amplification was carried out in a $25-\mu \mathrm{l}$ reaction mixture containing $10 \mathrm{mM}$ TrisHCL (pH 8.3), $50 \mathrm{mM} \mathrm{KCL}, 2 \mathrm{mM} \mathrm{MgCl}_{2}, 100 \mu \mathrm{M}$ each $\mathrm{dNTP}$, and $0.2 \mu \mathrm{M}$ each primer. The reaction was heated at $95^{\circ} \mathrm{C}$ for $10 \mathrm{~min} .$, then amplified for 40 cycles $\left[95^{\circ} \mathrm{C} /\right.$ $30 \mathrm{sec}$., $64^{\circ} \mathrm{C}$ (for RASSF1A) or $58^{\circ} \mathrm{C}$ (for DAPK) $/ 30 \mathrm{sec}$., and $72^{\circ} \mathrm{C} / 30 \mathrm{sec}$.], followed by a 10 -min.-final extension at $72^{\circ} \mathrm{C}$. Three microliters of each stage-I PCR product was diluted 10 -fold with water and $1-\mu$ l was used for stage-II PCR, using the same reagents and conditions as for stageI, except that the $\mathrm{MgCl}_{2}$ concentration was reduced to 1 $\mathrm{mM}$ and each sample was amplified in duplicated reaction, with one reaction containing primers specific for a methylated $\mathrm{C}$ and the other reaction containing primers specific for unmethylated $\mathrm{C}$. Each reaction was heated at $95^{\circ} \mathrm{C}$ for $10 \mathrm{~min}$., then amplified for 40 cycles each consisting, for the reaction containing methylated primers, of $95^{\circ} \mathrm{C} / 30 \mathrm{sec}$., $68^{\circ} \mathrm{C}$ (for RASSF $1 \mathrm{~A}$ ) or $66^{\circ} \mathrm{C}$ (for DAPK)/ $30 \mathrm{sec}$., and $72^{\circ} \mathrm{C} / 30 \mathrm{sec}$., and, for the reaction containing unmethylated primers, of $95^{\circ} \mathrm{C} / 30$ sec., $64^{\circ} \mathrm{C}$ (for RASSF $1 A$ ) or $68^{\circ} \mathrm{C}$ (for DAPK) $/ 30 \mathrm{sec}$., and $72^{\circ} \mathrm{C} / 30 \mathrm{sec}$., followed by a 10 -min.-final extension at $72^{\circ} \mathrm{C}$. Five microliters of each stage-II PCR product was separated on an $8 \%$ polyacrylamide gel. The gel was stained with ethidium bromide and photographed under UV illumination. The reproducibility of the results was confirmed by repeating the MSP analysis for each DNA sample. A portion of PCR products were purified using a MinElute PCR purification kit (QIAGEN, Valencia, CA) and directly sequenced to confirm methylation.

\section{Detection of K-ras, p53, and EGFR mutations}

Data on mutations in K-ras (codons 12 and 13), p53 (exons 5 - 8), and EGFR (exons 18-21) genes were obtained from our previous studies $[2,38,39]$.

\section{Statistical analysis}

Chi-square test or Fisher's exact test was used in univariate analysis. Logistic regression models were used to assess the effect of multiple variables on methylation status and relationship between genetic and epigenetic alterations.

\section{Results}

Overall, RASSF1A promoter methylation was detected in $46.7 \%(57 / 122)$ of the patients, a frequency that did not differ between smokers and never-smokers [48.1\% (39/ $81)$ vs. $43.9 \%(18 / 41), p=0.645]$, or between adenocarcinoma and the group of other tumor types [51.4\% (37/ $72)$ vs. $40 \%(20 / 50), p=0.210]$, or between stage-I and the group of other stages [51.9\% (28/54) vs. 40.7\% (22/ $54), \mathrm{p}=0.247]$. Promoter methylation for $D A P K$ was found in $32.8 \%(40 / 122)$ of the patients. When grouped according to the patient's smoking status, this gene meth- 
Table I: Demographic and clinical profile of I 22 NSCLC patients

\begin{tabular}{ll}
\hline Variable & cases $(\%)$ \\
\hline Age $\left(\right.$ mean \pm s.d. $\left.{ }^{*}\right)$ & $65.1 \pm 10.2$ \\
Gender & $52(42.6)$ \\
Male & $70(57.4)$ \\
Female & \\
Smoking status & $81(66.4)$ \\
Smoking & $41(33.6)$ \\
Never-smoking & $72(59.0)$ \\
Tumor types & $22(18.0)$ \\
Adenocarcinoma & $15(12.3)$ \\
Squamous cell carcinoma & $9(7.4)$ \\
Bronchioloalveolar carcinoma & $2(1.6)$ \\
Adenosquamous carcinoma & $1(0.8)$ \\
Large cell carcinoma & $1(0.8)$ \\
Carcinoid & \\
Neuroendocrine & $54(44.3)$ \\
Tumor stage & $24(19.7)$ \\
I & $19(15.6)$ \\
II & $11(9.0)$ \\
III & $14(11.5)$ \\
Unknown & \\
\hline
\end{tabular}

*: standard deviation

ylation was detected in $34.6 \%$ (28/81) of the smokers and was not significantly different from the $29.3 \%(12 / 41)$ frequency observed among the never-smokers ( $\mathrm{p}=$ $0.567)$. Furthermore, DAPK promoter methylation frequency did not differ between adenocarcinoma and the group of other tumor types [34.7\% (25/72) vs. 30\% (15/ $50), \mathrm{p}=0.583]$, or between stage-I and the group of other stages [31.5\% (17/54) vs. 31.5\% (17/54), $\mathrm{p}=1.000]$.

Multivariate logistic regression models were employed to control for the potential confounding effects of variables, such as age, gender, smoking status, tumor histology and tumor stage on methylation status of RASSF1A and DAPK genes. As shown in Table 2, age, gender, and smoking status did not significantly affect the methylation frequency of the RASSF1A or DAPK gene. Promoter methylation of RASSF1A was associated significantly with adenocarcinoma [the group of other tumor types vs. adenocarcinoma: odds ratio $(\mathrm{OR})=0.661,95 \%$ confidence interval $(\mathrm{CI})=0.454-0.962, \mathrm{p}=0.031]$, and marginally with early tumor stage (the group of other stages vs. stage-I: OR = $0.673,95 \% \mathrm{CI}=0.444-1.022, \mathrm{p}=0.063)$. Neither tumor histology nor tumor stage was associated with DAPK promoter methylation.

Among the 122 patients, 32 (26.2\%) had p53 mutations whereas $90(73.8 \%)$ had wild-type p53 [38]. The frequency of RASSF1A promoter methylation in patients with $p 53$ mutations was $56.3 \%$ (18/32) and was not significantly different from that in patients with wild-type p53 [43.3\% (39/90), $\mathrm{p}=0.212]$. Likewise, the DAPK promoter methylation frequency in patients with $p 53$ mutations was 25\% (8/32) and not different from that in patients with wild-type $p 53$ [35.6\% (32/90), $\mathrm{p}=0.331]$.

Thirty-six (29.5\%) of the 122 patients had K-ras mutations and 86 (70.5\%) had wild-type K-ras [2]. Among the K-ras mutation-positive patients, the frequency of RASSF1A promoter methylation was $41.7 \%(15 / 36)$ and was closely similar to the $48.8 \%(42 / 86)$ frequency in the group of patients with wild-type K-ras $(\mathrm{p}=0.474)$. Likewise, the frequency of DAPK promoter methylation was closely similar between the K-ras mutation-positive patients and patients with a wild-type K-ras [30.6\% (11/ $36)$ vs. $33.7 \%(29 / 86), p=0.735]$.

Data for EGFR mutations were obtained from a previous study [39] and were available for only 70 of the 122 patients involved in this study, including 40 never-smokers and 30 smokers. EGFR mutations were detected in $14.3 \%(10 / 70)$ of the patients and exclusively among the never-smokers (10/40, or 25\%), including 9 females and one male, and none among the smokers $(\mathrm{p}=0.002)$, and inversely correlated with K-ras mutations [0\% (0/10) vs. $28.3 \%(17 / 60), \mathrm{p}=0.049]$, in agreement with previous reports $[6,7,13,40]$. For comparison, EGFR mutations were found in both tumors with $p 53$ mutations and those without these mutations [30\% (3/10) vs. $28.3 \%(17 / 60)$, $\mathrm{p}=0.912]$, suggesting that, unlike K-ras mutations, $p 53$ mutations can occur in concert with EGFR mutations, in 
Table 2: Logistic regression models of DAPK and RASSFIA promoter methylation $(\mathrm{n}=122)$

\begin{tabular}{|c|c|c|c|c|}
\hline & \multicolumn{2}{|c|}{ DAPK } & \multicolumn{2}{|c|}{ RASSFIA } \\
\hline & OR $(95 \% \mathrm{Cl})$ & $\mathrm{P}$ & OR $(95 \% \mathrm{Cl})$ & $\mathrm{P}$ \\
\hline Age & $1.022(0.977-1.068)$ & 0.352 & $1.003(0.964-1.045)$ & 0.872 \\
\hline Sex & $1.911(0.746-4.894)$ & 0.177 & $1.203(0.513-2.822)$ & 0.671 \\
\hline Smoking & $1.743(0.642-4.732)$ & 0.275 & $1.006(0.410-2.469)$ & 0.990 \\
\hline Histology ${ }^{\dagger}$ & $0.709(0.465-1.082)$ & 0.111 & $0.661(0.454-0.962)$ & 0.031 \\
\hline Stage $\ddagger$ & $0.804(0.509-1.269)$ & 0.348 & $0.673(0.444-1.022)$ & 0.063 \\
\hline
\end{tabular}

OR: odds ratio; $\mathrm{Cl}$ : confidence interval.

$t$ : the group of other tumor types vs. adenocarcinoma.

¥: the group of other stages vs. stage $I$.

agreement with Kosaka's report $(\mathrm{p}=0.4634)$ [6]. EGFR mutations did not correlate with promoter methylation of RASSF1A or DAPK (data not shown).

Of the 122 patients, $100(81.9 \%)$ showed alterations of at least one gene, consisting of either promoter methylation of RASSF1A or DAPK, or mutations in the K-ras or $p 53$ gene. Furthermore, since K-ras mutations were found mostly among smokers, smoking patients showed a higher fraction of tumors with gene alterations, compared with the never-smoking patients $[87.6 \%(71 / 81)$ vs. $70.7 \%(29 / 41), \mathrm{p}=0.022]$. Of the 100 patients with alterations of at least one gene, $46(46 \%), 43$ (43\%), and 11 $(11 \%)$ showed alterations affecting one gene, two genes, and three or more genes, respectively. The frequency of cases with more than one gene abnormality did not differ between adenocarcinoma and the group of other tumor types, or between stage I and the group of other stages (data not shown). The EGFR mutations were not included in the calculation because they were available for only 70 of the 122 patients.

\section{Discussion}

The overall frequency of RASSF1A promoter methylation of $46.7 \%(57 / 122)$ in our study is similar to that found by Marsit et al [47\% (83/178)] [17] and correlated significantly with adenocarcinoma ( $\mathrm{p}=0.031$, table 2$)$, in agreement with some previous studies $[11,17,41]$, and marginally with tumor stage ( $\mathrm{p}=0.063$, table 2$)$. On the other hand, studies by Kim et al showed no such an association $[42,43]$.

The overall frequency of DAPK promoter methylation of $32.8 \%(40 / 122)$ found in the present study is in line with that reported by Toyooka's 37\% (14/38) [44] and was not associated with tumor histology ( $\mathrm{p}=0.111$, table 2$)$, in agreement with Kim's study [21], or with tumor stage $(\mathrm{p}=$ 0.348 , table 2). Data from previous studies are conflicting. For instance, in Kim's study DAPK promoter methylation was associated with advanced stages NSCLC $(p=0.009)$ [21], whereas in Russo's study it was detected mostly in early stages NSCLC [45]. This discrepancy might be due to limited number of patients in Russo's study $(\mathrm{n}=49)$ and/ or tumor stage data that were not available for some patients in our study. The frequencies of both RASSF1A and $D A P K$ gene promoter methylation were independent from the patients' smoking status ( $\mathrm{p}=0.990$ for RASSF1A and $\mathrm{p}=0.275$ for $D A P K$, table 2), consistent with the results of previous studies $[10,11,41,46]$.

There have been a few studies investigating the relationship between aberrant promoter methylation and mutations in oncogenes and tumor suppressor genes. Most of these studies compared promoter methylation of one or two genes with mutations in either the K-ras or $p 53$ gene $[41,43,46]$. Only two recent studies investigated the relationship between mutations of multiple oncogenes and/ or tumor suppressor genes and promoter methylation patterns but in lung cancer patients from Japan $[13,40]$. Here, we compared the promoter methylation status of RASSF1A and DAPK and mutations of K-ras, p53 and EGFR in the same lung tumors from lung cancer patients from the Western Pennsylvania region.

We observed no association of RASSF1A gene promoter methylation frequency with that of K-ras mutations ( $\mathrm{p}=$ 0.474 ), in agreement with previous studies $[11,41,43,46]$, or with the types of amino acid changes at codon 12 of the $\mathrm{K}$-ras gene (data not shown). Activated Ras has been associated with enhanced proliferation, transformation, and cell survival through a series of effectors, including RASSF1A. However, because the RASSF1A gene is a tumor suppressor gene, it is likely that loss of RASSF1A expression by promoter methylation in NSCLC does not require Ras activation. Thus, our findings suggest that RASSF1A inactivation may induce malignant transformation by some distinct mechanisms other than Ras-mediated antiapoptosis pathway, such as loss of genomic, microtubule stability and cell cycle regulation [14]. Furthermore, the prevalence of DAPK promoter methylation did not correlate with that of K-ras mutations $(\mathrm{p}=0.735)$, consistent with previous data $[11,21]$, suggesting that DAPK pro- 
moter methylation and K-ras mutations are independent events in non-small cell lung tumorigenesis.

The prevalence of RASSF1A promoter methylation in the present study did not correlate with that of $p 53$ mutations $(p=0.212)$. Previously, Endoh et al found a similar trend in their study of 100 NSCLC patients (21/56 wild-type $p 53$ vs. $21 / 44$ mutant $p 53, p=0.3165$ ) [41]. On the other hand, Tomizawa et al observed a weak association between RASSF1A promoter methylation and $p 53$ mutations (19/73 wild-type $p 53$ vs. $16 / 37$ mutant $p 53, \mathrm{p}=$ 0.0842 ) [46]. The discrepancy may be in part due to the difference in tumor stages in the different studies, with all patients in stage I lung adenocarcinoma tumors in Tomizawa's study and a mixed of tumors of different types [adenocarcinoma: 67\% (67/100) and 59\% (72/122)] and stages [stage I: $57 \%(57 / 100)$ and $44 \%(54 / 122)$ ] in Endoh's and our studies.

We observed no correlation between the prevalence of DAPK methylation and that of $p 53$ mutations $(\mathrm{p}=0.331)$, indicating DAPK promoter methylation and $p 53$ mutations may be independent events in NSCLC. DAPK, and a few other genes, have been reported to operate upstream to $p 53$ to induce apoptosis. For instance, Raveh et al found that the inactivation or loss of DAPK alone significantly reduces but not completely eliminates $p 53$ in response to c-Myc or E2F-1 [29]. Kim et al found that DAPK promoter methylation and $p 53$ mutations were not related in their study of 185 NSCLC patients $(\mathrm{p}=0.85)$ [21]. Thus, our results are consistent with those of these studies [21,29], suggesting that DAPK may be wired simultaneously to a few independent upstream branches of $p 53$, and may be involved in apoptosis without $p 53$ participation.

Results of our study based on 70 patients showed that EGFR mutations did not correlate with the RASSF1A or

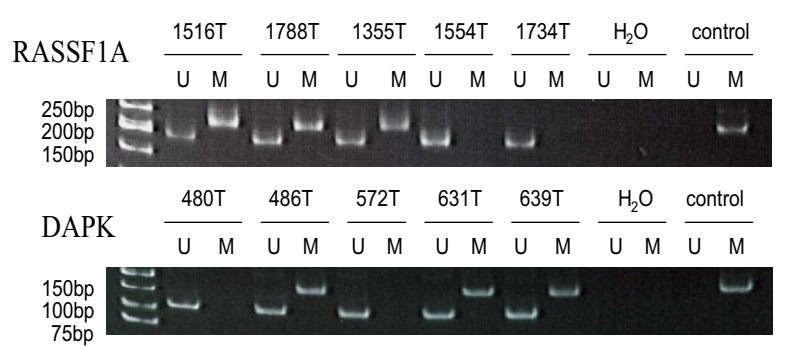

\footnotetext{
Figure I

Detection of RASSFIA and DAPK promoter methylation by MSP. M indicates the presence of methylated RASSFIA or DAPK. U indicates the presence of unmethylated RASSFIA or DAPK. All samples were performed twice and representative data are shown.
}

DAPK gene promoter methylation. Previously, there are only two studies investigating the relationship of RASSF1A promoter methylation and EGFR mutation, reporting absent [13] or borderline [47] correlation between these two events. The relationship between these mutations and DAPK promoter methylation has not been previously investigated. Furthermore, there have been only two previous studies of epigenetic and genetic alterations in multiple genes in lung tumors, both involving lung cancer patients from Japan. In the study by Toyooka et al [13], mutations in the EGFR and K-ras genes were compared with promoter methylation of five genes in lung adenocarcinomas from 164 patients. There was no significant association between RASSF1A promoter methylation frequency and the K-ras or EGFR mutation frequency. Our data are in agreement with this finding. In the study by Suzuki et al [40], EGFR, HER-2, and K-ras mutations were compared with promoter methylation of nine genes in 150 NSCLC patients. The authors observed that EGFR mutation had an inverse correlation with promoter methylation of the secreted protein acidic and rich in cysteine and $p 16$ genes. However, K-ras mutations were detected at a lower fraction of the tumor, compared with our study ( 6 out of 150 versus 36 out of 122) and was not investigated in relation to RASSF1A methylation.

The relationship between epigenetic and genetic alterations has also been investigated in other tumor types. For instance, in sporadic colorectal cancer and pancreatic cancer, RASFF1A promoter methylation was found predominantly in tumors with K-ras wild type $[48,49]$. Another study showed that sporadic colorectal cancer exhibiting microsatellite instability harbored concomitant RASSF1A gene promoter methylation and mutations in the K-ras and/or B-raf genes [50].

Taken together, results from these studies and our present study indicated the need for further investigation of the interaction between genetic and epigenetic alterations in lung tumors in an ethnically diverse patient population in order to further understand the development of lung cancer.

\section{Conclusion}

Promoter methylation of the RASSF1A and DAPK genes was frequent in lung tumors from patients with primarily NSCLC, all of whom were Caucasian and from the Western Pennsylvania region. Furthermore, there was a significant association between promoter methylation of the RASSF1A gene and tumor histology, specifically adenocarcinoma. However, there was no significant association of the prevalence of promoter methylation of either gene with the smoking status of the patients or with the status of mutations in the K-ras, p53, or EGFR gene, suggesting 
each of these events may occur independently in lung tumorigenesis.

\section{Competing interests}

The author(s) declare that they have no competing interests.

\section{Authors' contributions}

YL carried out the methylation analysis, and drafted the manuscript; WG performed K-ras and p53 mutations and participated in the analysis and interpretation of data; JMS and JDL provided lung tumor samples, demographic/clinical information of patients and data interpretation; JLW performed statistical analysis and interpretation of data; PK designed and supervised the study, analyzed and interpreted data.

\section{Acknowledgements}

We thank Dr. Dianxu Ren, Center for Research \& Evaluation, School of Nursing \& Department of Biostatistics, University of Pittsburgh, for helping in the statistical analysis of data. This work was supported by grants from the American Cancer Society (grant \#RPG-99-161-0I-CNE and grant \#RSG-99-16I-04-CNE).

\section{References}

I. Hecht SS: Tobacco smoke carcinogens and lung cancer. J Natl Cancer Inst 1999, 9 I: I 194-1210.

2. Keohavong P, DeMichele MA, Melacrinos AC, Landreneau RJ, Weyant RJ, Siegfried JM: Detection of K-ras mutations in lung carcinomas: relationship to prognosis. Clin Cancer Res 1996, 2:4II-4I8.

3. Gealy R, Zhang L, Siegfried JM, Luketich JD, Keohavong P: Comparison of mutations in the $\mathrm{p} 53$ and $\mathrm{K}$-ras genes in lung carcinomas from smoking and nonsmoking women. Cancer Epidemiol Biomarkers Prev 1999, 8:297-302.

4. Ahrendt SA, Decker PA, Alawi EA, Zhu YrYR, Sanchez-Cespedes M, Yang SC, Haasler GB, Kajdacsy-Balla A, Demeure MJ, Sidransky D: Cigarette smoking is strongly associated with mutation of the K-ras gene inpatients with primary adenocarcinoma of the lung. Cancer 200I, 92:1525-1530.

5. Pao W, Miller V, Zakowski M, Doherty J, Politi K, Sarkaria I, Singh B, Heelan R, Rusch V, Fulton L, Mardis E, Kupfer D, Wilson R, Kris M, Varmus $H$ : EGF receptor gene mutations are common in lung cancers from "never smokers" and are associated with sensitivity of tumors to gefitinib and erlotinib. Proc Natl Acad Sci USA 2004, I01: I3306-I33|1.

6. Kosaka T, Yatabe Y, Endoh H, Kuwano H, Takahashi T, Mitsudomi T: Mutations of the epidermal growth factor receptor gene in lung cancer: biological and clinical implications. Cancer Res 2004, 64:8919-8923.

7. Shigematsu H, Lin L, Takahashi T, Nomura M, Suzuki M, Wistuba II, Fong KM, Lee H, Toyooka S, Shimizu N, Fujisawa T, Feng Z, Roth JA, Herz T, Minna JD, Gazdar AF: Clinical and biological features associated with epidermal growth factor receptor gene mutations in lung cancers. J Natl Cancer Inst 2005, 97:339-346.

8. Husgafvel-Pursiainen K, Boffetta P, Kannio A, Nyberg F, Pershagen G, Mukeria A, Constantinescu V, Fortes C, Benhamou S: p53 mutations and exposure to environmental tobacco smoke in a multicenter study on lung cancer. Cancer Res 2000, 60:2906-29II.

9. Kim DH, Nelson HH, Wiebcke JK, Zheng S, Christiani DC, Wain JC, Mark E], Kelsey KT: p I 6(INK4a) and histology-specific methylation of CpG islands exposure to tobacco smoke in nonsmall cell lung cancer. Cancer Res 200I, 6 I:3419-3424.

10. Toyooka S, Maruyama R, Toyooka KO, Mclerran D, Feng Z, Fukuyama Y, Virmani AK, Zochbauer-Muller S, Tsukuda K, Sugio K, Shimizu N, Shimizu K, Lee H, Chen CY, Fong KM, Gilcrease M, Roth JA, Minna JD, Gazdar AF: Smoke exposure, histologic type and geography-related differences in the methylation profiles of non-small cell lung cancer. Int J Cancer 2003, I03:153-160.

II. Divine KK, Pulling LC, Marron-Terada PG, Liechty KC, Kang T, Schwartz AG, Bocklage TJ, Coons TA, Gilliland FD, Belinsky SA: Multiplicity of abnormal promoter methylation in lung adenocarcinomas from smokers and never smokers. Int J Cancer 2005, I | 4:400-405.

12. Liu Y, Lan Q, Siegfried JM, Luketich JD, Keohavong P: Aberrant promoter methylation of $\mathrm{pl} 6$ and MGMT genes in lung tumors from smoking and never-smoking lung cancer patients. Neoplasia 2006, 8:46-5।.

13. Toyooka S, Tokumo M, Shigekatsu H, Matsuo K, Asano H, Tomii K, Ichihara S, Suzuki M, Aoe M, Date H, Gazda AF, Shimizu N: Mutational and epigenetic evidence for independent pathways for lung adenocarcinomas arising in smokers and never smokers. Cancer Res 2006, 66:137|-1375

14. Agathanggelou A, Cooper WN, Latif F: Role of the Ras-association domain family tumor suppressor gene in human cancers. Cancer Res 2005, 65:3497-3508.

15. Dammann R, Li C, Yoon JH, Chin PL, Bates S, Pfeifer GP: Epigenetic inactivation of a RAS association domain familyprotein from the lung tumour suppressor locus 3p21.3. Nat Genet 2000, 25:3|5-3|9.

16. Burbee DG, Forgacs E, Zochbauer-Muller S, Shivakumar L, Fong K, Gao B, Randle D, Kondo M, Virmani A, Bader S, Sekido Y, Latif F, Milchgrub S, Toyooka S, Gazda AF, Lerman MI, Zabarovsky E, White $M$, Minna JD: Epigenetic inactivation of RASSFIA in lung and breast cancers and malignant phenotype suppression. J Natl Cancer Inst 2001, 93:691-699.

17. Marsit CJ, Kim DH, Liu M, Hinds PW, Wiencke JK, Nelson HH, Kelsey KT: Hypermethylation of RASSFIA and BLU tumor suppressor genes in non-small cell lung cancer: implications for tobacco smoking during adolescence. Int J Cancer 2005, I 1 4:219-223.

18. Shohat G, Shani G, Eisenstein M, Kimchi A: The DAP-kinase family of proteins: study of a novel group of calcium-regulated death-promoting kinases. Biochim Biophys Acta 2002, 1600(12):45-50.

19. Inbal B, Cohen O, Polak-Charcon S, Kopolovic J, Vadai E, Eisenbach L, Kimchi A: DAP kinase links the control of apoptosis to metastasis. Nature 1997, 390:180-184

20. Tang X, Khuri FR, Lee J], Kemp BL, Liu D, Hong WK, Mao L: Hypermethylation of the death-associated protein (DAP) kinase promoter and aggressiveness in stage I non-small-cell lung cancer. I Natl Cancer Inst 2000, 92: I5 I I-15 I6.

21. Kim DH, Nelson HH, Wiencke JK, Christiani DC, Wain JC, Mark EJ, Kelsey KT: Promoter methylation of DAP-kinase: association with advanced stage in non-small cell lung cancer. Oncogene 200I, 20:1765-I770.

22. Baylin SB, Ohm JE: Epigenetic gene silencing in cancer - a mechanism for early oncogenic pathway addiction? Nat Rev Cancer 2006, 6: 107-116.

23. Rouleau J, Macleod AR, Szyf M: Regulation of the DNA methyltransferase by the Ras-AP-I signaling pathway. J Biol Chem 1995, 270:1595-1601.

24. Macleod AR, Rouleau J, Szyf M: Regulation of DNA methylation by the Ras signaling pathway. I Biol Chem 1995, 270: II327-II337.

25. Vos MD, Ellis CA, Bell A, Birrer MJ, Clark GJ: Ras uses the novel tumor suppressor RASSFI as an effector to mediate apoptosis. J Biol Chem 2000, 275:35669-35672.

26. Khokhlatchev A, Rabizadeh S, Xavier R, Nedwidek M, Chen T, Zhang $X F$, Seed B, Avruch J: Identification of a novel Ras-regulated proapoptotic pathway. Curr Biol 2002, I 2:253-265.

27. Feig LA, Buchsbaum RJ: Cell signaling: life or death decisions of ras proteins. Curr Biol 2002, I 2:R259-26I.

28. Ortiz-Vega S, Khokhlatchev A, Nedwidek M, Zhang XF, Dammann R, Pfeifer GP, Avruch J: The putative tumor suppressor RASSFIA homodimerizes and heterodimerizes with the Ras-GTP binding protein Nore I. Oncogene 2002, 21:138|-|390.

29. Raveh T, Droguett G, Horwitz MS, DePinho RA, Kimchi A: DAP kinase activates a pl9ARF/p53-mediated apoptotic checkpoint to suppress oncogenic transformation. Nat Cell Biol 200 I, 3:1-7.

30. Gottlieb TM, Oren M: p53 in growth control and neoplasia. Biochim Biophys Acta 1996, 1287:77-102. 
31. Ko LJ, Prives C: p53: puzzle and paradigm. Genes Dev 1996, 10:1054-1072.

32. Arteaga $C L$ : Overview of epidermal growth factor receptor biology and its role as a therapeutic target in human neoplasia. Semin Oncol 2002, 29:3-9.

33. Paez JG, Janne PA, Lee JC, Tracy S, Greulich H, Gabriel S, Herman P, Kaye FJ, Lindeman N, Boggon TJ, Naoki K, Sasaki H, Fujii Y, Eck MJ, Sellers WR, Johnson BE, Meyerson M: EGFR mutations in lung cancer: correlation with linical response to gefitinib therapy. Science 2004, 304: I497-I500.

34. Lynch TJ, Bell DW, Sordella R, Gurubhagavatula S, Okimoto RA, Brannigan BW, Harris PL, Hasserlat SM, Supko JG, Haluska FG, Louis DN, Christiani DC, Settleman J, Haber DA: Activating mutations in the epidermal growth factor receptor underlying responsiveness of non-small-cell lung cancer to gefitinib. N Engl J Med 2004, 350:2129-2139.

35. Herman JG, Graff JR, Myohanen S, Nelkin BD, Baylin SB: Methylation-specific PCR: a novel PCR assay for methylation status of CpG islands. Proc Natl Acad Sci USA 1996, 93:982I-9826.

36. Palmisano WA, Divine KK, Saccomanno G, Gilliland FD, Baylin SB, Herman JG, Belinsky SA: Predicting lung cancer by detecting aberrantpromoter methylation in sputum. Cancer Res 2000 , 60:5954-5958.

37. Belinsky SA, Palmisano WA, Gilliland FD, Crooks LA, Divine KK, Winters SA, Grimes MJ, Harms HJ, Tellez CS, Smith TM, Moots PP, Lechner JF, Stidley CA, Crowell RE: Aberrant promoter methylation in bronchial epithelium and sputum from current and former smokers. Cancer Res 2002, 62:2370-2377.

38. Gao WM, Mady HH, Yu GY, Siegfried JM, Luketich JD, Melhem MF, Keohavong P: Comparison of p53 mutations between adenocarcinoma and squamous cell carcinoma of the lung: unique spectra involving $\mathbf{G}$ to $\mathbf{A}$ transitions and $\mathbf{G}$ to $\mathbf{T}$ transversions in both histologic types. Lung Cancer 2003, 40: I4I-I50.

39. Zhang W, Stabile LP, Keohavong P, Romkes M, Grandis JR, Traynor AM, Siegfried JM: Mutation and polymorphism in the EGFR-TK domain associated with lung cancer. J Thorac Oncol 2006, I:635-647.

40. Suzuki M, Shigematsu H, lizasa T, Hiroshima K, Nakatani Y, Minna JD, Fujisawa $\mathrm{T}$ : Exclusive mutation in epidermal growth factorreceptor gene, HER-2, and KRAS, and synchronous methylation of nonsmall cell lung cancer. Cancer 2006, 106:2200-2207.

4I. Endoh H, Yatabe Y, Shimizu S, Tajima K, Kuwano H, Takahashi T, Mitsudomi T: RASSFIA gene inactivation in non-small cell lung cancer and its clinical implication. Int J Cancer 2003, 106:45-51.

42. Kim DH, Kim JS, Ji YI, Shim YM, Kim H, Han J, Park J: Hypermethylation of RASSFIA promoter is associated with theage at starting smoking and a poor prognosis in primary non-smallcell lung cancer. Cancer Res 2003, 63:3743-3746.

43. Kim DH, Kim JS, Park JH, Lee SK, Ji YI, Kwon YM, Shim YM, Han J, Park J: Relationship of Ras association domain family I methylation and K-ras mutation in primary non-small cell lung cancer. Cancer Res 2003, 63:6206-62II.

44. Toyooka S, Toyooka KO, Miyajima K, Reddy JL, Toyota M, Sathyanarayana UG, Padar A, Tockman MS, Lam S, Shivapurkar N, Gazdar AF: Epigenetic down-regulation of death-associated protein kinase in lung cancers. Clin Cancer Res 2003, 9:3034-3041.

45. Russo AL, Thiagalingam A, Pan H, Califano J, Cheng KH, Ponte JF, Chinnappan D, Nemani P, Sidransky D, Thiagalingam S: Differential DNA hypermethylation of critical genes mediates the stagespecific tobacco smoke-induced neoplastic progression of lung cancer. Clin Cancer Res 2005, I I:2466-2470.

46. Tomizawa $Y$, Kohno T, Kondo H, Otsuka A, Nishioka M, Niki T, Yamada T, Maeshima A, Yoshimura K, Saito R, Minna JD, Yokota J: Clinicopathological significance of epigenetic inactivation of RASSFIA at $3 \mathrm{p} 2 \mathrm{I} .3$ in stage I lung adenocarcinoma. Clin Cancer Res 2002, 8:2362-2368.

47. Tomizawa $Y$, lijima $H$, Sunaga N, Sato $K$, Takise A Otani $Y$, Tanaka $S$, Suga T, Saito R, Ishizuka T, Dobashi K, Minna JD, Nakajima T, Mori M: Clinicopathologic significance of the mutations of the epidermal growth factor receptor gene in patients with nonsmall cell lung cancer. Clin Cancer Res 2005, I I:68I 6-6822.

48. Van Engeland M, Roemen GM, Brink M, Pachen MM, Weijenberg MP, de Bruine AP, Arends JW, van den Brandt PA, de Goeij AF, Herman JG: K-ras mutations and RASSFIA promoter methylation in colorectal cancer. Oncogene 2002, 21:3792-3795.
49. Dammann R, Schagdarsurengin U, Strunnikova M, Rastetter M, Seidel C, Liu L, Tommasi S, Pfeifer GP: Epigenetic inactivation of the Ras-association domain family I (RASSFIA) gene and its function in human carcinogenesis. Histol Histopathol 2003, I 8:665-677.

50. Oliveira C, Vello S, Domingo E, Preto A, Hofstra RM, Hamelin R, Yamamoto H, Seruca R, Schwartz S Jr: Concomitant RASSFIA hypermethylation and KRAS/BRAF mutations occur preferentially in MSI sporadic colorectal cancer. Oncogene 2005, 24:7630-7634.

\section{Pre-publication history}

The pre-publication history for this paper can be accessed here:

http://www.biomedcentral.com/1471-2407/7/74/prepub

Publish with Biomed Central and every scientist can read your work free of charge

"BioMed Central will be the most significant development for disseminating the results of biomedical research in our lifetime. "

Sir Paul Nurse, Cancer Research UK

Your research papers will be:

- available free of charge to the entire biomedical community

- peer reviewed and published immediately upon acceptance

- cited in PubMed and archived on PubMed Central

- yours - you keep the copyright

BioMedcentral 